\title{
Issues in Security, Good Governance and its Challenges to Economic Growth and Development
}

\author{
Alhaji Ahmadu Ibrahim \\ Yobe State University, Department of Sociology, \\ Pmb 1144 Damaturu Yobe State. \\ Email: ialhaji@rocketmail.com, bursarima@gmail.com
}

\section{Doi:10.5901/mjss.2013.v4n13p187}

\section{Abstract}

\begin{abstract}
Security is tied to both social, political and economic growth and development of Nigeria. The negligence of the security sector is responsible for the non-performance of democratic governance and its attendant violent crimes, such as armed robbery, ethnic crisis, electoral violence, kidnapping, police brutality, etc. The relationship between democratic governance and security is not automatic in Nigeria. Therefore this paper uses available sources of data as its method or technique of data collection and analyse the missing gaps between security and development. The paper advance its findings and suggest some recommendations, some of which are, provision of an appropriate infrastructure for good governance, rule of law, overhauling the security sector to meet the challenges of law enforcement, surveillance and protective service delivery, creation of employment opportunities, and programmes to embark on total moral re-orientation of the citizens among others.
\end{abstract}

\section{Introduction}

First October, 2013, will mark Nigeria's 53' independence anniversary. Just as with individuals, over fiftieth years in the life of a nation calls for in-depth reflection on where we are as a nation compared to where we ought to be, what are the missing gaps, what are the lessons from the past to enable the nation face its social reality with courage and determination.

Liberal scholars see the state as a product of social contract, an outcome of the escape from the state of nature in which according to Thomas Hobbes life was "nasty, brutish and short." According to these liberal theorist, men surrendered their power to a single sovereign, hence the social contract and emergence of the state. Under this arrangement security is one of the most fundamental ingredients to sustain the contract, because without security there will be no peace, order and stability, a situation in which the existence of an entity could not be guaranteed.

However, after a long experience of military dictatorship, civilian rule in 1999 brought high expectations for peace and progress in the living condition of Nigerians. However, democracy has failed so far to deliver good governance and in its place, insecurity, poverty, economic crisis and social problems have become the fate of Nigerians. The liberalization of the political atmosphere in 1999 brought by civil rule was used for the mobilization of primordial sentiments and identity politics (Alubo 2011). Therefore, insecurity and violence with its dire consequences in terms of loss of lives, property and injury has become widespread and rampant. According to Alubo (2011, pg 2) in the first fifty-five months of civil rule December 2003, about 80 major violent eruptions were recorded. The Economists reported that as at 2001, more than 6000 people have been killed (Cited in Alubo 2011, pg 3).

For instance, the cases of armed robbery on Nigeria's high ways, banks, and households, the Niger Delta militants, the ethnic and religious crises as witnessed in Maiduguri (Boko haram), Jos, Ibadan, and other parts of the country that claimed a lot of innocent souls and destroyed properties worth billions of naira are pointers to security lapses in the country. The cases of electoral violence in both 2003, 2007 and 2011 elections and the recent by-election in Gombe, Bauchi, other parts of the state, the cases of kidnapping citizens in demand of ransom and worst of all the brutal killings of Nigerians by the police that are saddled with the primary responsibility of protecting the property and lives of citizens through torture in the name of investigation and direct shooting on the excuse of accidental discharge, as indicated by the Human Rights Report 2010, are all evidences to the fact that good governance is lacking in Nigeria.

Security, including "human security", is a critical foundation for sustainable development. This implies protection from systemic human rights abuses, physical threats, violence, and extreme economic, social, and environmental risks, territorial and sovereignty threats. It is a primary prerequisite and goal for poor people to make a lasting improvement in their lives (UNIDIR, Report 2008). 
Therefore, security should be given utmost attention and priority above all other interest in the state, because it determines the unity, integration and peaceful co-existence that ensure the corporate existence of the country as an entity that will device a viable and efficient alternative for social, political and economic growth and development within the limited resource at its disposal.

\section{Conceptualising the Concepts}

It is important to conceptualize our key words in the discourse, that is, security, good governance, and economic growth and development.

\subsection{National security}

According to the Microsoft Encarta 2007, is the concept of safety for the territory and population of a state, and by extension the policies adopted for its preservation, security is sometimes defined as the assurance of future welfare. In this broad sense national security might be regarded as the whole range of measures affecting the economic and social welfare of a population, as well as provision against aggression from abroad or subversion from within.

\subsection{Good governance}

According to the United Nations commission on human rights, governance is the process whereby public institutions conduct public affairs, manage public resource and guarantee the realization of human rights. Good governance accomplishes this in a manner essentially free of abuse and corruption, and with due respect and regards for the rule of law. The true test of good governance is the degree to which it delivers on the promise of human rights. The key question is, are the institutions of governance effectively guaranteeing the right to health, adequate housing, sufficient food, quality education, fair justice and personal security? (HRD 2003, P.1).

Good governance is all about effective and transparent leadership that produces results which together transform the socio-economic conditions of a nation. The objective of good governance is human development with equity and social justice. The goal of governance should be to develop capacities that are needed to realize development that gives priority to the poor, advances women, sustains the environment and creates needed opportunities for employment and other livelihoods, (UNDP, 1999).

\subsection{Economic growth and development}

According to the academic dictionary of sociology economics is the scientific study of production, distribution, and consumption of goods and services. The function of the economic institution is to provide for the material needs and demand of the members of the society, ranging from the basic means for survival to goods intended for conspicuous consumption. On the other hand, growth and development are both qualitative and quantitative increase in certain economic variables such as gross domestic product (GDP), per capital income etc., (Alanana, 2006). Therefore, economic growth and development are embodied in any policy that will ensure the positive improvement and sustainability of certain economic variables of a state.

\section{Theoretical Frame Work}

To appreciate and understand the issue of insecurity and good governance in Nigeria, we must situate our discourse within the general context of the Nigerian state and its political economy. At independence, we inherited a neo-colonial state which was anchored on economic dependency on former colonial powers for manufactured goods. This was based on the export of agricultural goods and other mineral resources particularly groundnut, cocoa, palm oil and oil in the 1970s. A network of multinational co-operations was given coverage to operate, Royal Niger Company among others. The neo-colonial state which Nigeria is one solely depended on foreign loan, grant and aid with conditions attached that are usually stiff ones. And this is happening in league with the professional indigenous bourgeois class in the civil service, military and police service and the intelligentsia. This class became intermediaries between the masses of Nigerian workers and peasants on the one hand and the neo-colonial state on the other.

According to dependency theorist, the cause of underdevelopment is the dependence on industrialized countries 
while internal factors of developing countries such as Nigeria are considered irrelevant or seen as symptoms and consequence of dependence. The development of the industrialized countries and the underdevelopment of developing countries are parts of one historical process. Developing countries such as Nigeria are largely dependent as such the political and economic interest of industrialised countries determines their development or under development (Schafer, 2005:20)

The dependency theory suggests that multi or transnational corporations and organizations such as the IMF, and World Bank have contributed to making third world countries dependent on first world countries for economic survival. The theory states that this dependence is self-maintaining because the economic systems tend to benefit the first world countries and corporations. Scholars also question whether the idea of development is biased in favour of Western thought. They debated whether population growth is a main source of problems in the third world or if the problems are more complex and thorny than that. Policy makers disagree on how much involvement first world countries should have in the third world and whether third world debts should be cancelled.

\section{Security Condition in Nigeria}

Since the inception of democratic governance in 1999, the federal government of Nigeria has done little, if not nothing, to improve on human rights and protection of its citizen's life and property as one of their cardinal responsibilities. Instead they turn to be a threat to the wellbeing and corporate existence of their citizens as part of their mandate and statutory responsibility as contained in the constitution.

For instance, bloody sectarian clashes claimed hundreds of lives in late 2008 and 2009, while the government failed to investigate, much less hold accountable, members of the security forces implicated in numerous incidents of extra judicial killings, torture, and extortion, (HRW, 2010). The government's amnesty for militants in the Niger Delta failed to address the root causes of the violence. The government demonstrated a lack of political will to reform the police, who were again implicated in numerous extra judicial killings of persons in custody, torture of criminal suspects, and wide spread corruption.

On July 30, 2009, the police in the northern city of Maiduguri brazenly executed the Boko Haram leader Mohammed Yusuf in police custody, the following day his father-in-law Baba Mohammed and a former state government official suspected of funding Boko Haram, Buji Foi, were also reportedly killed in police custody. The government promised to promptly investigate these killings, but to no avail (HRW 2010).

In November 2008 the police and military were credibly implicated in more than 130 unlawful killings while responding to the election related violence in Jos. The government has still not held members of the security forces accountable for past crimes, including the massacre of more than 200 people by the military in Benue state in 2001 and military's complete destruction of the town of Odi in Bayelsa state in 1999. (Suleiman 2010)

Inter communal, political, and sectarian violence have claimed the lives of more than 13,500 people during the past decade in Nigeria. Nigerian politicians continue to manipulate ethnic and religious tensions by sponsoring violence for personal political gain, and wide spread poverty and poor governance have created an environment where militant groups can thrive. Violent clashes in July between government security forces and a militant Islamist group in northern Nigeria known as boko haram left at least 800 dead. In November 2008 more than 700 people were killed during two days Christian Muslim sectarian clashes following a disputed local government election in the central city of Jos. (Suleiman, 2010)

The government has still not held accountable those responsible for the 2007 election violence that left at least 300 dead while a closely fought gubernatorial rerun election in Ekiti sate in April 2009 was again marred by violence, vote rigging and fraud. Nevertheless, Nigeria's judiciary continuous to exercise a degree of independence in electoral matters, since 2007 the courts have overturned one third of the PDP gubernatorial election victories on the ground of electoral malpractice or other irregularities, (HRW, 2010)

\section{Good Governance and its Challenges to Economic Development in Nigeria}

To show case the importance of good governance to economic development, the UNDP has been in the forefront of the growing international consensus, that good governance and sustainable human development are indivisible, and that the development of the capacity for good governance is the primary way to eliminate poverty. If good governance through good leadership is so important for sustained economic development and prosperity, then Nigerians have no choice but to make good governance the cornerstone of development, (Richardson 2008). 
The key features of good governance have been identified to include but limited to:

$\checkmark$ Transparency,

$\checkmark$ Responsibility,

$\checkmark$ Accountability,

$\checkmark$ Participation,

$\checkmark$ Responsiveness to the need of the people,

$\checkmark$ Efficiency in public administration,

$\checkmark$ Development oriented budgeting.

Good governance places great emphasis on pragmatic strategies for achieving positive and cost effective results in public administration. Good governance also ensures the rule of law, promotes due process, improves efficiency, facilitates accountability, tackles corruption, salute excellence, insist on productivity, and delivers high quality services to the people, (Democracy and the challenges of development in Nigeria 2005).

To achieve pragmatic and cost effective results, good governance must excel in two critical spheres:

1. Improving the management of public resources through reforms covering public sector institutions, such as the treasury, central bank, public enterprises, civil service, etc., and refining the procedures of expenditure control, budget management and revenue collection.

2. Supporting the development and maintenance of a transparent and stable economic and regulatory environment conducive to efficient private sector activities, e.g. price system, exchange and trade regimes, banking systems, etc., (IMF, 1997, P.11 cited in the democracy and the challenges of development in Nigeria 2005).

However, there are central questions and challenges, among which is the challenge to sustain and maintain democracy and turn it to a way of life acceptable and workable for the largest majority of our people. This involves managing internal tendencies, especially security issues and problems that could impinge on the survival of democracy. This should be considered as a matter of national importance by all stakeholders in Nigeria and one that requires comprehensive and committed contribution of all groups and interests that make up Nigeria (Abubakar 2004).

In addressing the challenges of good governance in Nigeria, it is important to consider security issues and problems that have affected the attitude, confidence and cooperation of all groups and segments that make-up the Nigerian federation. Some of the major security challenges or threats that reach its apex in Nigeria are among other things, the political and electioneering conflicts, socio economic agitations, ethno religious crisis, ethnic militia, boundary dispute, cultism, criminality, and organised crimes. These challenges individually and collectively constitute threats to not only the democracy but to the existence of the country (Nigeria) as a single entity. (Abubakar 2004)

Notwithstanding, it is a fact that, for the better part of more than 50 years as a nation, Nigeria was under military administration resulting from takeover of the democratic and constitutional structures of the state. The military takeovers are security breaches resulting from a wide range of reasons, sometimes a culmination of a number of security and political developments, security, political and sometimes economic developments which are security concerns that were not addressed or managed by the existing state structures at the time.

Another challenge for economic development was that, there have been several ethno religious conflicts in the history of Nigeria, but since the inception of democratic governance in 1999 these problems appeared to be escalating at an intolerable scale. Ethnic crisis and the foregoing challenges individually and collectively create insecurity and breach of peace that are likely to, or indeed affect legitimate social and economic activities in the country. These challenges have also posed serious threats and send wrong signals to the international communities that Nigeria is not a save place for investment.

The leadership and other stakeholders should provide good governance and followership to reflect and improve on the policy and institutional means of dealing with security concerns arising in the country.

\section{Recommendations}

* There is strong need for the process of legislative and constitutional review to assess the country's constitution and amend or expunge where necessary areas that are found creating conflicts and insecurity.

* To overcome and outgrow the problem of security in Nigeria, it is pertinent that political actors and institutions embrace the principles of true democracy and allow open, free and fair competition that are essential in the process of aggregation of National Union and development choices.

* The government should improve its infrastructure, education system, and power and communication sectors 
and create more employment to the teaming unemployed youth.

* Federal government of Nigeria should undertake a comprehensive assessment of the physical environment of the Niger delta taking into consideration impact of oil spillage, exploration and democratize access to environmental laws and compensation regimes for the oil gas activities, and empower communities to participate in community budgeting and environmental protection measures and processes.

* There is need to enhance effectiveness of security operatives through training and retraining, and provision of modern equipment and improve their welfare.

\section{References}

Abubakar, A., (2004), the challenges of security in Nigeria. Guest lecture at NIPSS, Kuru

Academic's Dictionary of Sociology 2006, New Delhi, Star Offset Printers, Eddy Asae Nigeria press, Lagos

Alanana, (2006), Sociology of development: An introduction, Kaduna, Joyce Printers

Amnesty international 2010 Report

Gana, J., (ed, 2005), Democracy and challenges of development in Nigeria, Abuja

Human Rights in Development, 2003

Human Rights Watch, world Report 2010- Nigeria

Microsoft Encarta Encyclopaedia Standard 2007

Miller, and Rudnick, (2008), the security needs assessment protocol: Improving operational effectiveness through community security, UNIDIR

NEWSWATCH, Monday, February 21, 2005

Ogoh, A., (2011), ethnic conflicts and citizenship crises in central Nigeria

Pikay Richardson, (2008), Good governance: The challenges of leadership in Africa. Manchester Business School, UK

Sharma, S., (2007), Taiwan Journal of Democracy, Volume 3, No. 29-26

UNDP, Development Report, 1999

Victor Odozi, (2002), the Imperatives of Economic Development in Nigeria. 
